\title{
Effect of diet composition and frequency of feeding on postprandial insulin level and ovarian follicular development in prepubertal pigs*
}

\author{
A.J. Zięcik ${ }^{1}$, W. Kapelański ${ }^{2}$, M. Zaleska ${ }^{1}$ and J. Riopérez ${ }^{3}$ \\ 'Institute of Animal Reproduction and Food Research. Polish Academy of Sciences \\ Tuwima 10, 10-746 Olsztyn. Poland \\ ${ }^{2}$ Department of Pig Breeding, University' of Technology and Agricullure \\ Mazowiecka 28,85-084 Bydgoszcz, Poland \\ ${ }^{3}$ Intituto de Nutrición y Bromatologia, Faculdad de Famacia, Ciudad Universitaria \\ 280-40, Madrid, Spain
}

(Received 22 March 2002; accepted 2 August 2002)

\begin{abstract}
Several studies have shown that insulin is positively related to reproductive processes. The objectives of the present study were to investigate the effect of threc diets, consisting of different major energy sources (starch, glucose or fat) given in 2,3 or 4 portions daily on postprandial glucose and insulin levels, and to assess the influence of 3 times a day feeding on follicular development in prepubertal gilts.

In Experiment 1, Polish Landrace gilts aged 142 days $(n=18)$ were randomly divided into three equal groups $(n=6)$ fed with starch, glucose and fat diet. The same animals received their diet in three frequencies (2,3 or 4 times daily). Each period started with three days of adaptation to the of the same diet. On day 4 , blood samples were taken before, during and after feeding. The next day the frequency of feeding was changed without change of diet. The plasma glucose and insulin concentrations were determined by enzymatic- and radioimmunoassay, respectively.

In Experiment 2, forty-four 140 day old gilts were divided into three treatment groups and given starch, glucose and fat diets in three equal portions at $8.00,13.00$ and $18.00 \mathrm{~h}$. After 25 days of experimental feeding gilts were slaughtered the day after treatment to assess: ovarian weight, follicular development and the total number of LH receptors in one ovary.

Basal plasma glucose concentrations were similar for the three diets given 3 and 4 times a day (3 times daily: $50.8 \pm 4.9,56.8 \pm 4.0,56.3 \pm 7.4 \mathrm{mg} / \mathrm{dl} ; 4$ times daily: $53.3 \pm 1.7,65.8 \pm 5.9,58.3 \pm 7.5$ $\mathrm{mg} / \mathrm{dl})$, but differed $(\mathrm{P}<0.05)$ for the three diets given twice daily $(71.4 \pm 10.4,40.8 \pm 3.9,53.6 \pm 8.6$ $\mathrm{mg} / \mathrm{dl}$, starch, glucose, fat, respectively). The basal plasma insulin concentration was similar for the three diets and different frequency of feeding ( 2 times daily: $7.8 \pm 1.4,9.3 \pm 1.0,9.5 \pm 0.9 \mu l \mathrm{l} / \mathrm{ml}$;
\end{abstract}

- Supported by the State Committee for Scientific Rescarch, Grant No. P06D 00716 and partly by the Intemational Atomic Energy Agency (IAEA) technical co-operation fund, POL/5/010 
3 times daily: $6.2 \pm 1.4,10.3 \pm 1.0,8.6 \pm 1.0 \mu \mathrm{IU} / \mathrm{ml}$ and 4 times daily: $8.5 \pm 1.6,7.9 \pm 0.8,8.2 \pm 2.7 \mu \mathrm{IU} / \mathrm{ml}$, starch, glucose and fat, respectively). After feeding, the insulin concentration in gilts fed the glucose or starch diet showed a faster increase compared with the fat diet in all studied periods of teeding. The area under the total curve for the plasma insulin level was greater $(P<0.05)$ for the glucose diet than for fat diet (6870 1656 vs $4028 \pm 751$ arbitrary units, respectively for twice daily feeding; $6314 \pm 718$ vs $3274 \pm 472$, respectively for three daily feeding), whereas the starch diet was intermediate $(6104 \pm 762$ and $3855 \pm 729$, respectively) and not significantly different from the other diets. Four daily feeding diet not caused significant differences for starch, fat and glucose diets in area under curve for insulin level. Feeding the starch, glucose and fat diets for 25 days (in three equal portions) did not affect the weight $(\mathrm{g})$ of the ovary $(2.8 \pm 0.1,2.8 \pm 0.2$ and $3.0 \pm 0.1$, respectively), the number and size of healthy and atretic follicles nor $\mathrm{LH}$ receptor concentration $(9.0 \pm 1.2 ; 10.5 \pm 1.7$ and $9.6 \pm 1.2 \mathrm{fM} / \mathrm{mg}$ protein, respectively).

The results confirmed earlier observations that the dietary energy source affects the postprandial plasma insulin concentrations when the diet is divided into two parts. A similar effect was observed when the diet was given in three, but not four, equal portions each day. However, three times daily increase of insulin concentration in blood samples for 25 days did not affect ovarian and follicular developinent in prepubertal gilts of pure Polish Landrace breed.

KEY WORDS: insulin, glucose, puberty attainment, gilts

\section{INTRODUCTION}

It is desirable to induce early puberty attainment in the gilt as she is a costly non-productive animal until the initiation of her first pregnancy. There are many factors which can be manipulated in order to reduce age of puberty and hence minimize the cost of introducing replacement gilts. The major ones are growth rate, nutrition, genetics, climate and the animals' social environment (Hughes, 1982). Increasing dietary energy intake of gilts' four or more days before oestrus has been reported to increase their ovulation rate (Robertson et al., 1951; Zimmerman et al., 1960; Dailey ct al., 1972). The hormonal mechanisms involved in these increases in ovulation rate remain largely undefined. The metabolic hormone, insulin has been implicated as necessary for reproductive processes in some studies (Siegel and Wade, 1979; Kirchick et al., 1982). Several studies have shown that insulin can be positively related to follicular development (Matamoros et al., 1990; Tokach et al., 1992; Cox et al., 1997). Plasma insulin levels can be altered by feeding level (Booth et al., 1996) or exogenous insulin injections (Cox et al., 1997). Van den Brand et al. (1997) showed that the nature of the dietary energy source can affect the postprandial plasma insulin concentration.

The objectives of the present study were to investigate the effect of three different diets consisting of different energy sources (starch, glucose and fat) given 2, 3 or 4 times daily on postprandial insulin concentrations, and to determine if three times daily feeding influenced follicular development in prepubertal gilts. 


\section{MATERIAL AND METHODS}

In Experiment 1, Polish Landrace gilts aged 142 days $(\mathrm{n}=18)$ were randomly divided into three equal groups $(n=6)$ fed with starch, glucose and fat diet (see below). The same animals received their diet in three frequencies $(2,3$ or 4 times daily). Each period started with three days of adaptation to the diet and frequency (2: 8.00 and $18.00 \mathrm{~h} ; 3: 8.00,13.00$ and $18.00 \mathrm{~h} ; 4: 8.00,11: 30,15: 00$ and $18: 30 \mathrm{~h}$ ). Gilts were housed individually in $9 \mathrm{~m}^{2}$ pens. The day before the experiment began all gilts were surgically fitted with a permanent jugular catheter according to the method previously described by Kotwica et al. (1978). On day four of each frequency-feeding period, blood samples were taken before via the catheter, during and after each feed. Following sampling, the feeding frequency was changed. Three experimental diets were prepared (Table I) and all consisted of a basal diet with sufficient protein, vitamins and minerals (according to Polish Norms of Pig Nutrition, 1993). The carbohydrate-rich-diet (starch) contained $391.3 \mathrm{~g} / \mathrm{kg}$ starch and

TABLE 1

Composition of experimental diets

\begin{tabular}{lccc}
\hline & \multicolumn{3}{c}{ Dict } \\
\cline { 2 - 4 } Ingredients & glucose & fat & starch \\
\hline Barley & $\mathrm{g}$ & $\mathrm{g}$ & $\mathrm{g}$ \\
Wheat middlings & 240 & 240 & 587 \\
Toasted soyabean & 55 & 55 & 100 \\
Extracted soyabean & 57 & 57 & - \\
Supplement of extracted sunflower seed* & 115 & 115 & 140 \\
Extracted rape seed & 178 & 178 & - \\
Meat-and-bone meal & 40 & 40 & - \\
Lucerne meal & 50 & 50 & 30 \\
Wheat bran & 2 & 2 & 20 \\
Maize starch & - & - & 100 \\
Glucose & 178 & - & - \\
Tallow & 60 & - & - \\
Chatk & - & 81 & 5 \\
Monocalcium phosphate & 8.1 & 8.1 & 10 \\
Salt & 7.1 & 7.1 & 3 \\
L-Lysine & 2.4 & 2.4 & - \\
DL-Methionine & 1.2 & 1.2 & - \\
Premix & 1.2 & 1.2 & 5 \\
Calculated content & 5 & 5 & $\mathrm{~g} / 1000 \mathrm{~g}$ \\
crude protein & & & 190 \\
starch & $\mathrm{g} / 1000 \mathrm{~g}$ & $\mathrm{~g} / 843 \mathrm{~g}$ & 391.3 \\
MJ NE (for pig daily) & 200 & 200 & 12 \\
\hline
\end{tabular}

* ingredients: barley-15\%, extracted soyabean- $25 \%$, meat-and-bone meal-30\%, lucerne meal-15\%, extracted rape seed $15 \%$ 
$12 \mathrm{MJ}$ of net energy (NE). In the carbohydrate/glucose-enriched diet (glucose) $27 \mathrm{~g}$ of starch from the starch diet was replaced with $60 \mathrm{~g}$ of glucose. The glucose diet additionally contained $178 \mathrm{~g}$ of maize starch and less barley (Table 1). The fat-enriched diet (fat) contained $96.1 \mathrm{~g} / \mathrm{kg}$ of tallow as the major energy source. The glucose and fat diets were isocaloric (12.3 MJ NE daily according to Hoffman et al., 1972).

At the beginning and end of the experiment gilts were weighed. Blood samples were taken at $-60,-48,-36,-24,-12,0,12,24,36,48,120,150,220$ min relative to the $8.00 \mathrm{~h}$ feeding. Blood samples were collected in ice-cooled polypropylene tubes containing $0.3 \mathrm{M}$ EDTA and $1 \%$ aspirin $(\mathrm{pH} 7.4$ ), then centrifuged at $1500 \times \mathrm{g}$ for $15 \mathrm{~min}$ at $4^{\circ} \mathrm{C}$. The plasma was stored at $-20^{\circ} \mathrm{C}$ until analysis. The plasma insulin concentration was quantified in one radioimmunoassay using the commercial kit Coat-A-Count Insulin (Diagnostic Products Corporation, Los Angeles, CA, USA). The maximum binding for ${ }^{125} \mathrm{I}$-insulin was $46 \%$. The sensitivity was $4 \mu \mathrm{IU} / \mathrm{ml}$ at $80 \%$ binding. The intraassay coefficient of variation (CV) was $5.1 \%$, whereas interassay coefficient of variation was $7.1 \%$. The plasma glucose concentration was measured by oxidase test using the commercial kit (Alpha-Diagnostic Ltd., Warsaw, Poland).

In Experiment 2, forty-four 140 day old Polish Landrace gilts were divided into three treatment groups and given starch $(n=14)$, glucose $(n=15)$ or fat $(n=15)$ diets in three equal portions at $8.00,13.00$ and $18.00 \mathrm{~h}$ as described in Experiment 1. After 25 days of experimental feeding, gilts were slaughtered the next day after treatment to assess: ovarian weight, follicular development and the total number of LH receptors in one ovary. Ovaries collected from each gilt were weighed and then one ovary was immediately frozen in liquid nitrogen for further determination of LH receptors. The other ovary was placed in Bouin's fluid, embedded in paraffin and serially sectioned. Every fiftieth section $(6 \mu \mathrm{m})$ was stained with haematoxylin-eosin. In each section all antral follicles were microscopically counted. All measured follicles were morphologically classified as healthy or atretic on the basis of degenerative changes as the presence of pycnotic nuclei and/or local destruction of the basement membrane. The follicles were divided into three size classes: small $<1 \mathrm{~mm}$, medium 3-6 $\mathrm{mm}$ and large $>6 \mathrm{~mm}$ in diameter.

$\mathrm{LH}$ receptor levels were determined, as previously described, and validated (Ziecik et al., 1989; Jana et al., 1996). Briefly, ovaries were thawed, homogenized in six volumes ( $\mathrm{v} / \mathrm{w}$ ) of $25 \mathrm{mmol} / \mathrm{l} \mathrm{Tri} \mathrm{HCl}$ buffer $\mathrm{pH} 7.4$ containing $2.50 \mathrm{mmol} / \mathrm{l}$ of sucrose at $4^{\circ} \mathrm{C}$ with an Ultra-Torax homogenizer. The homogenate was then filtered through four layers of cheesecloth, and the filtrate was centrifuged for $20 \mathrm{~min}$ at $800 \mathrm{~g}$ at $4^{\circ} \mathrm{C}$. The supernatant was centrifuged further for one hour at $25000 \mathrm{xg}$ at $4{ }^{\circ} \mathrm{C}$ and the sediment suspended in $3 \mathrm{ml}$ of icc-cold $25 \mathrm{mmol} / \mathrm{l}$ Tris- $\mathrm{HCl}$ buffer, $\mathrm{pH} 7.2 \mathrm{con}$ taining $0.1 \% \mathrm{BSA}$ and $5 \mathrm{mmol} / \mathrm{lMgCl}_{2}$. Finally, obtained membrane fractions were assayed for protein determination by the method of Lowry et al. (1951).

hCG (CR-127) was labclled using the chloramines-T method (Greenwood et al., 1963; Catt and Dufau, 1975). Non-specific binding was measured by the addition 
of 1 ng unlabelled hCG and was less than $2 \%$ of the total ${ }^{125}$ I-labelled hCG added. The concentration of $\mathrm{LH} / \mathrm{hCG}$, unoccupied binding sites and association constants $\mathrm{Ka}$ for hormone binding to receptors were determined using the EBDA computer program (Elsevier BIO-SOFT, Cambridge, UK). Seven subsaturating quantities of unlabelled hCG $(0.15-5 \mathrm{ng})$ were used for each receptor preparation.

All data were presented as mean \pm SEM. Glucose and insulin concentrations were compared by one-way analysis of variance (ANOVA). Both basal glucose and basal insulin concentrations were calculated per gilt per period by repeated measures ANOVA as the mean value of the samples taken at $60,48,36,24,12$ and 0 min before feeding. The area under the curve during the sampling period $(0-240 \mathrm{~min})$ was calculated as the area corrected for basal glucose and insulin concentrations.

\section{RESULTS}

\section{Experiment 1}

The gilts body weight $(\mathrm{kg})$ at the start of experiment was $63.3 \pm 1.4$ on starch diet, $63.2 \pm 1.2$ on glucose diet and $64.7 \pm 2.0$ on fat diet, and at the end of experiment was $83.6 \pm 2.9,85.7 \pm 1.5$ and $86.1 \pm 3.6$, respectively.

Basal plasma glucose concentrations were similar in the three diets given 3 and 4 times a day (3 times: $50.8 \pm 4.9,56.2 \pm 4.0,56.3 \pm 7.4 \mathrm{mg} / \mathrm{dl} ; 4$ times: $53.3 \pm 1.7$, $65.8 \pm 5.9,58.3 \pm 7.5 \mathrm{mg} / \mathrm{dl}$ ), but differed in the three diets given twice daily $(71.4 \pm 10.4,40.8 \pm 3.9,53.6 \pm 8.6 \mathrm{mg} / \mathrm{dl}$, starch, glucose, fat, respectively; $\mathrm{P}<0.05$ glucose vs starch). Pre-feeding basal plasma glucose concentrations in gilts fed twice daily were lowest for glucose, intermediate for fat and highest for starch group. All groups showed a similar increase of glucose concentration in plasma after feeding which resulted in the same rate of glucose concentrations 120-240 min after feeding (Figure 1). There were also differences in plasma glucose concentration 120-240 min after feeding in diets given twice daily ( $\mathrm{P}=0.06$, glucose vs starch).

The basal plasma insulin concentration was similar for three diets fed 2,3 and 4 times daily ( 2 times: $7.8 \pm 1.4,9.3 \pm 1.09 .5 \pm 0.9 \mu \mathrm{IU} / \mathrm{ml} ; 3$ times: $6.2 \pm 1.4,10.3 \pm 1.0$, $8.6 \pm 1.0 \mu \mathrm{IU} / \mathrm{ml}$ and 4 times: $8.5 \pm 1.6,7.9 \pm 0.8,8.2 \pm 2.7 \mu \mathrm{IU} / \mathrm{ml}$, starch, glucose and fat, respectively; Figure 2). After feeding, the insulin concentration in gilts fed the glucose or starch diet showed a faster increase compared with the fat diet in all studied feeding periods. This resulted in a significantly $(\mathrm{P}<0.05)$ differed plasma insulin level 24-48 min after feeding ( $\mathrm{P}<0.05$ glucose vs starch and fat in gilts fed 3 times daily; $\mathrm{P}<0.05$ glucose vs fat in gilts fed twice daily; Figure 2). The highest differences in insulin concentration among starch, glucose and fat diets 24-48 min after feeding were found in gilts fed 3 times daily $(53.8 \pm 7.7 \mathrm{vs} 22.3 \pm 1.6$ and $27.5 \pm 2.7$, respectively; $P<0.05$ ). In gilts fed twice daily the significant differences 
Feeding $2 \mathrm{x}$ daily

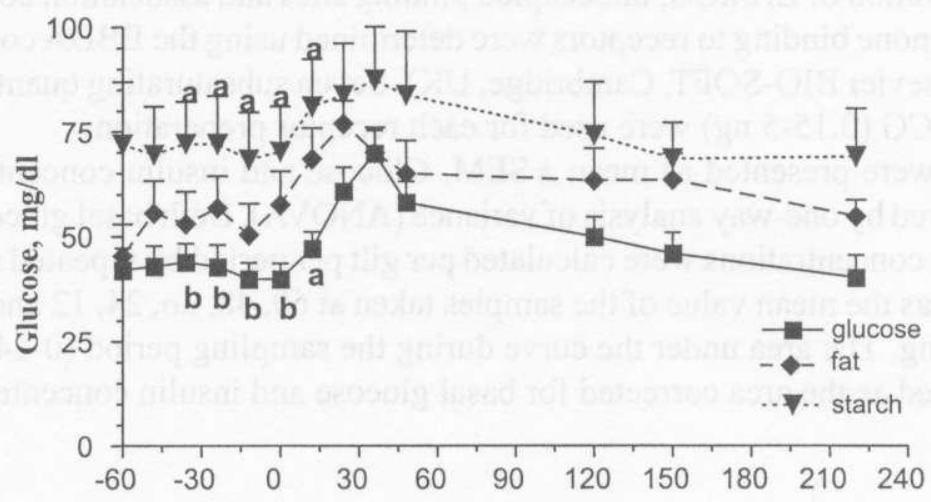

Feeding $3 \mathrm{x}$ daily

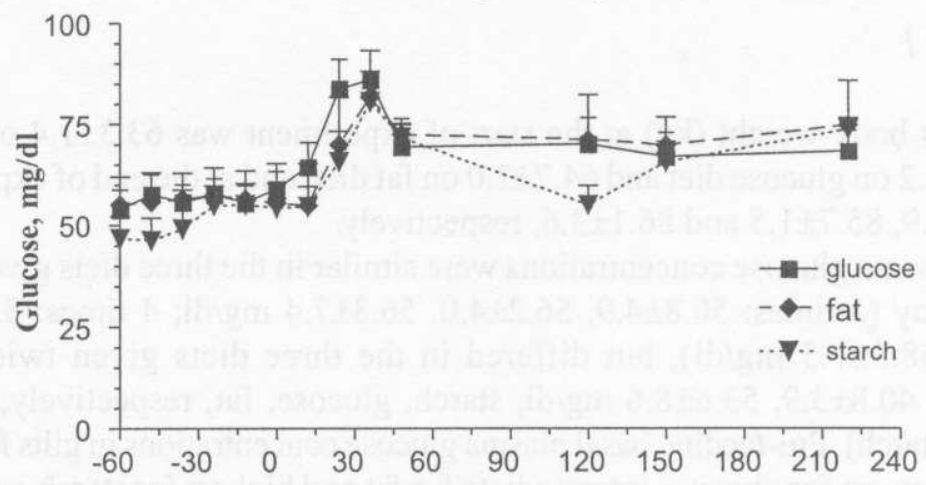

Feeding $4 \mathrm{x}$ daily

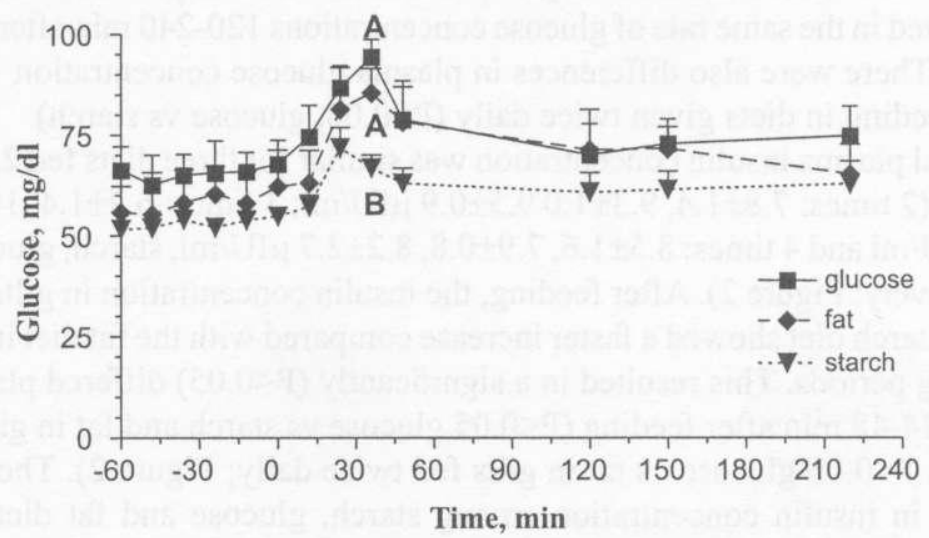

Figure 1. Pre- and post-feeding plasma glucose concentration (means $\pm \mathrm{SEM}$ ) for gilts given starch, glucose and fat enriched diets in two, three or four equal feed per day $(a>b, P<0.05 ; A>B, P<0.01)$ 
Feeding $2 \mathrm{x}$ daily
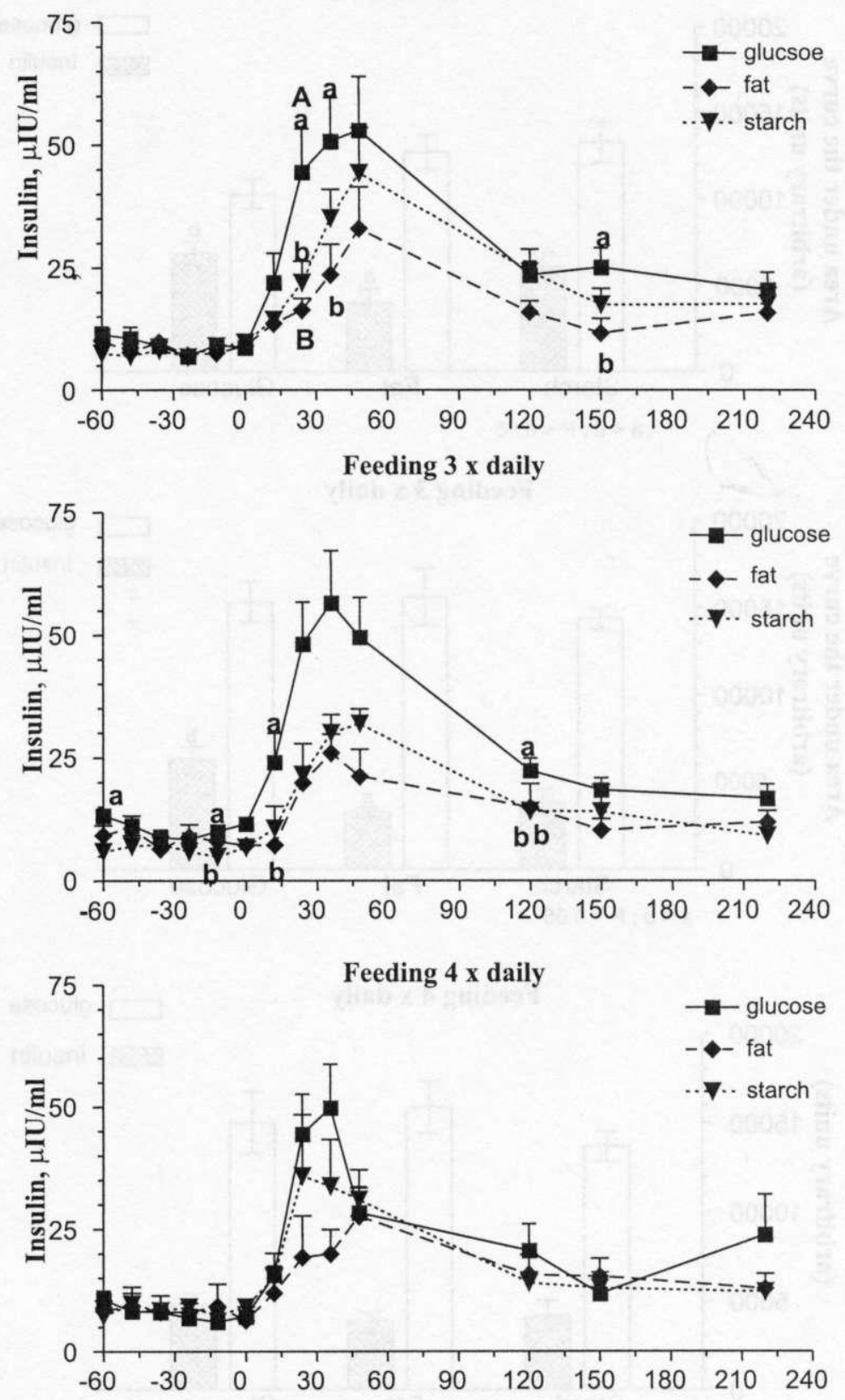

Time. min

Figure 2. Pre- and post-feeding plasma insulin concentration (means \pm SEM) for starch, glucose and fat groups $(\mathrm{a}>\mathrm{b}, \mathrm{P}<0.05 ; \mathrm{A}>\mathrm{B}, \mathrm{P}<0.01)$ 

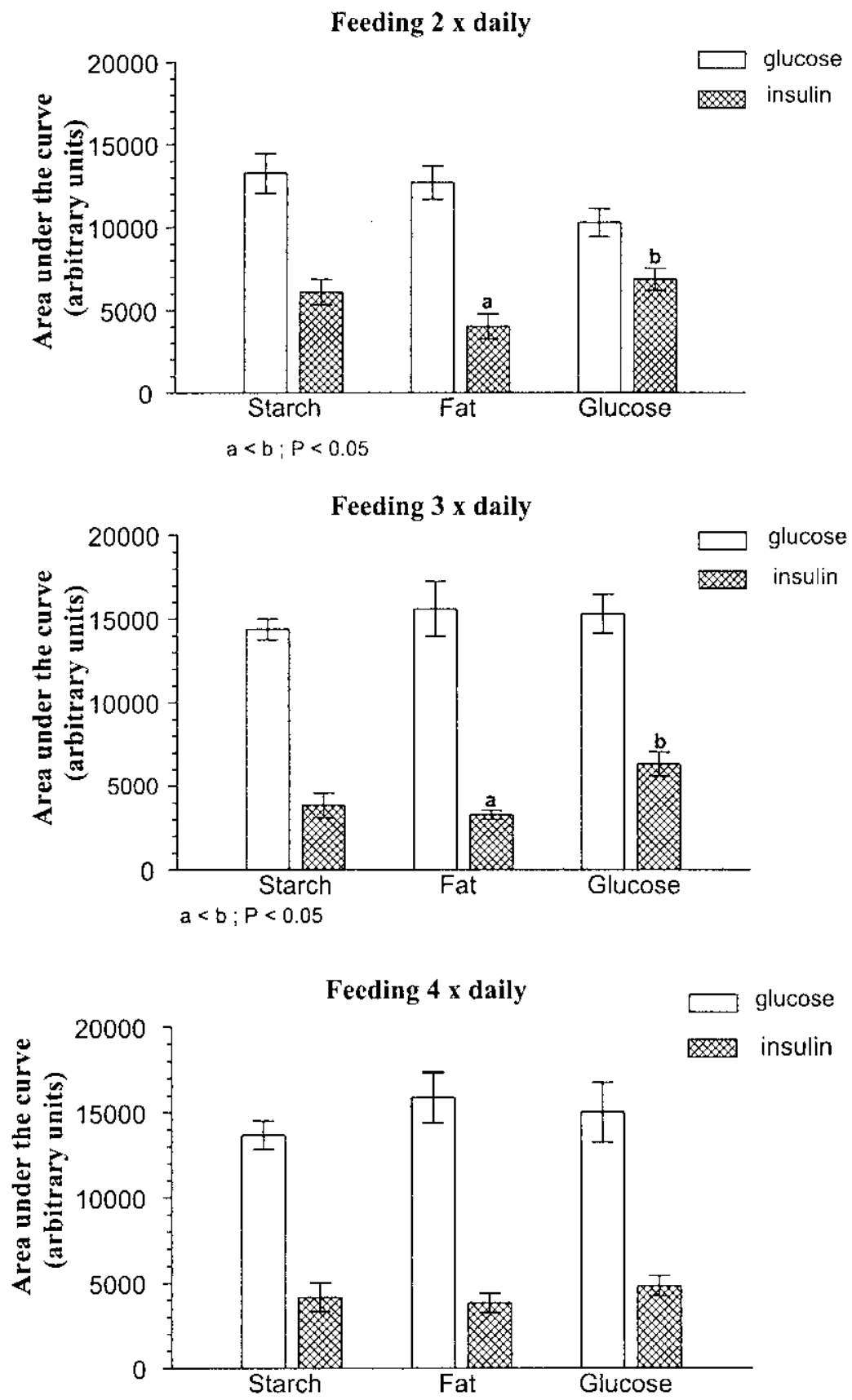

Figure 3. Area under the curve for plasma insulin and glucose during the period of $240 \mathrm{~min}$ after providing feed in relation to feeding schedule for gilts given starch, glucose and fat diets (means \pm SEM) 
were between glucose and fat diets $(48.8 \pm 6.3$ vs $24.3 \pm 5.0 ; \mathrm{P}<0.05)$. The plasma insulin level 120-240 min after feeding differed between diets when they were given three times daily ( $\mathrm{P}=0.07$, fat vs starch). The maximum and minimum insulin concentrations occurred when gilts were given the glucose and fat diets in all feeding periods. Those for the starch diet were intermediate and did not differ significantly from the other two diet types.

The area under the total curve for plasma insulin level was greater for the glucose diet than for the fat diet ( 2 meals per day: $6870 \pm 656 \mathrm{vs} 4028 \pm 751$; 3 meals per day: $6314 \pm 718$ vs $3274 \pm 472$ arbitrary units, respectively), whereas the starch dict was intermediate for 2 and 3 meals per day $(6104 \pm 762$ and $3855 \pm 729$, respectively; Figure 3 ) and not significantly different from the other diets. Four daily feeding did not caused significant differences for starch, fat and glucose diets in area under curve for insulin level $(4165 \pm 840,3840 \pm 574$ and $4837 \pm 602$, respectively).

Analyses within diets and the feeding period showed a significant maximum insulin and minimum glucose (basal glucose $-G_{B A S \wedge L}$ ) in gilts fed twice daily. The maximum plasma insulin level and the maximum plasma glucose concentration ratio ( $\mathrm{I}_{\mathrm{MAX}} / \mathrm{G}_{\mathrm{MAX}}$, both $24-48$ min after feeding) significantly decreased in starch and fat diets when compared to the glucose diet in 2 and 3 frequency periods (glu$\operatorname{cose}>$ starch $>$ fat; Table 2 ). Differences in the ratio of the maximum plasma insulin level ( $\mathrm{I}_{\mathrm{MAX}}, 24-48$ min after feeding) and the basal plasma glucose concentration $\left(G_{B \wedge S \wedge L},[-60]-0\right.$ min after feeding) were similar to $I_{M A X} / G_{M A X}$ in those same frequencies of feeding. However, in gilts fed twice daily this relationship was different (glucose $>$ fat $>$ starch, Table 2). There were also differences in the ratio of insulin and glucose area under the total curve $\left(\mathrm{I}_{\mathrm{AREA}} / \mathrm{G}_{\mathrm{AREA}}\right.$; Table 2$)$.

TABLE 2

Values of ratio $I_{M A X} / G_{M A X}, I_{M A X} / G_{B A S A L}, l_{A R I A} . G_{A R F A}$. in three diets and frequencies of fecding

\begin{tabular}{|c|c|c|c|c|}
\hline $\begin{array}{l}\text { Frequency } \\
\text { of feeding }\end{array}$ & $\begin{array}{c}\text { Energy } \\
\text { source } \\
\text { (diel) }\end{array}$ & $\mathrm{I}_{\mathrm{MAX}} / \mathrm{G}_{\mathrm{MAX}}$ & $I_{\text {MAX }} / G_{\text {IBASAl. }}$ & $\mathrm{I}_{\Lambda R E A^{*}} / \mathrm{G}_{\mathrm{ARE: \Lambda ^{* }}}$ \\
\hline 2 & $\begin{array}{l}\mathrm{G} \\
\mathrm{F} \\
\mathrm{S}\end{array}$ & $\begin{array}{c}0.8 \pm 0.1^{\mathrm{a}} \\
0.4 \pm 0.1^{\mathrm{b}} \\
0.4 \pm 0.1\end{array}$ & $\begin{array}{l}1.3 \pm 0.2^{\mathrm{a}} \\
0.6 \pm 0.2^{\mathrm{b}} \\
0.5 \pm 0.1^{\mathrm{b}}\end{array}$ & $\begin{array}{c}0.7 \pm 0.1^{\star} \\
0.3 \pm 0.1^{\mathrm{b}} \\
0.5 \pm 0.0^{\circ}\end{array}$ \\
\hline 3 & $\begin{array}{l}\mathrm{G} \\
\mathrm{F} \\
\mathrm{S}\end{array}$ & $\begin{array}{l}0.6 \pm 0.0^{\mathrm{a}} \\
0.3 \pm 0.1^{\mathrm{b}} \\
0.4 \pm 0.0^{\mathrm{b}}\end{array}$ & $\begin{array}{l}0.9 \pm 0.1^{\mathrm{a}} \\
0.4 \pm 0.1^{\mathrm{b}} \\
0.6 \pm 0.1\end{array}$ & $\begin{array}{c}0.4 \pm 0.0^{\mathrm{a}} \\
0.2 \pm 0.0^{\mathrm{b}} \\
0.3 \pm 0.0\end{array}$ \\
\hline 4 & $\begin{array}{l}G \\
F \\
S\end{array}$ & $\begin{array}{l}0.5 \pm 0.1 \\
0.3 \pm 0.1 \\
0.5 \pm 0.1\end{array}$ & $\begin{array}{l}0.7 \pm 0.1 \\
0.4 \pm 0.1 \\
0.6 \pm 0.1\end{array}$ & $\begin{array}{l}0.4 \pm 0.1 \\
0.2 \pm 0.0 \\
0.3 \pm 0.1\end{array}$ \\
\hline
\end{tabular}

* under total curve

$\mathrm{S}$ - starch, G-glucose, F-fat; $\mathrm{a}>\mathrm{b}, \mathrm{P}<0.05$ in columns for 2 and 3 frequency of feeding $\mathrm{I}_{\mathrm{MAX}}-$ maximum insulin, $\mathrm{G}_{\mathrm{MAX}}-$ maximum glucose, $\mathrm{G}_{\mathrm{BASAl}}$ - basal glucose levels, respectivcly $I_{A R F A}, G_{A R E A}-$ area under the curve of insulin (l) and glucose $(G)$ levels 


\section{Experiment 2}

The twenty-five day glucose, starch and fat diets divided into three equal portions daily did not affect the weight of ovary $(2.8 \pm 0.1,2.8 \pm 0.2$ and $3.0 \pm 0.1 \mathrm{~g}$, respectively). The number and size of healthy and atretic follicles did also not change (Table 3).

The $\mathrm{LH}$ receptor concentration (fM/mg protein) was similar in all the glucose, starch and fat groups $(9.0 \pm 1.2 ; 10.5 \pm 1.7$ and $9.6 \pm 1.2$, respectively).

TABLE 3

Summary of ovarian weights, number of follicles and concentration of LH receptors per on ovary in gilts fed 25 days ( 3 times daily) with starch, glucose and fat diets ( \pm SEM)

\begin{tabular}{|c|c|c|c|c|c|c|c|c|}
\hline \multirow{3}{*}{ Group } & \multirow{3}{*}{$\begin{array}{l}\text { Weight } \\
\text { of ovary } \\
\mathrm{g}\end{array}$} & \multicolumn{6}{|c|}{ Total number of follicles } & \multirow{3}{*}{$\begin{array}{c}\text { LIf } \\
\text { receplors } \\
\mathrm{fM} / \mathrm{mg} \\
\text { protein }\end{array}$} \\
\hline & & \multicolumn{2}{|c|}{$<3 \mathrm{~mm}$} & \multicolumn{2}{|c|}{$3-6 \mathrm{~mm}$} & \multicolumn{2}{|c|}{$>6 \mathrm{~mm}$} & \\
\hline & & héalthy & atretic & hearty & atretic & healthy & atretic & \\
\hline $\begin{array}{l}\text { Starcl } \\
(n=14)\end{array}$ & 2.8 & $25.8 \pm 2.3$ & $12.4 \pm 14$ & $1.3 \pm 0.3$ & $0.6 \pm 0.3$ & $0.2 \pm 0.2$ & - & $10.5 \pm 1.7$ \\
\hline $\begin{array}{l}\text { Glucose } \\
(n=15)\end{array}$ & 2.8 & $27.9 \pm 6.3$ & $12.9 \pm 2.0$ & $0.9 \pm 0.2$ & $0.6 \pm 0.3$ & $0.2 \pm 0.2$ & - & $9.0 \pm 1.2$ \\
\hline $\begin{array}{l}\text { Fat } \\
(n=15)\end{array}$ & 3.0 & $26.4 \pm 3.8$ & $15.0 \pm 1.7$ & $1.1 \pm 0.3$ & $0.7 \pm 0.2$ & - & - & $9.6 \pm 1.2$ \\
\hline
\end{tabular}

\section{DISCUSSION}

The aim of this study was to investigate the effects of specific dietary sources on the plasma glucose and insulin concentrations, and the reproductive tract and ovarian development in prepubertal gilts of pure Polish Landrace breed. The composition of experimental diets (glucose and fat) was based on that proposed by Van den Brand et al. (1997) with slight modifications (supplementation of extracted sunflower seed in glucose and fat diets, and an addition of wheat bran to the starch diet). Van den Brand et al. (1997) used their experimental diets for mature gilts fed twice daily. In our experiment, diets were additionally divided into three and four portions, and the plasma glucose and insulin profiles were determined. The postprandial patterns of the plasma glucose concentration in our study were similar to those found by Ponter et al. (1991) and Van den Brand et al. (1997) only when gilts were fed 3 and 4 times daily. In these cases there were no differences between diets in basal plasma glucose concentrations before feeding in gilts fed three various diets. However, in gilts fed the glucose diet twice daily, the basal glucose level was the lowest and significantly different when compared to the diet rich in starch. It can be explained by the highest insulin release and maintenance at high level after feeding in gilts fed the glucose-enriched diet. 
It is interesting that such a relationship between plasma glucose and insulin concentrations was not found in gilts fed 3 times daily, but gilts fed the glucoseenriched diet maintained the highest postprandial insulin levels in blood. The highest basal pre-feeding level of plasma glucose in the fat-enriched diet can be explained by the relatively low insulin release after feeding.

Generally, our results obtained in prepubertal gilts confirmed the data of Van den Brand et al. (1997) that a dietary energy source affects the postprandial plasma insulin levels when the isocaloric diet is divided in two parts in mature gilts. Additionally, we were able to show the same effect when three but not four equal portions were applied. However, three times daily increase of insulin concentration in blood samples during a period of 25 days has not influenced follicular development in purebred prepubertal gilts.

The failure of the glucose-enriched and insulin generating diet to influence follicular development could be caused by two factors: (1) too young and low body weight gilts used in experiments and (2) the use of pure-bred gilts. Age and body weight are very important factors for the attainment of puberty in gilts (Hughes, 1982; Britt et al., 1989). On the other hand, pure breeds reach puberty approximately 3-4 weeks later than hybrids (Hughes, 1982).

To confirm our hypothesis we used in the next experiments with the glucoseenriched diet, slightly older (10-15 days) and crossbred gilts to study natural and PMSG/hCG induced puberty attainment in gilts. In those studies the addition of glucose to a standard diet given in three portions daily speeded up the attainment of puberty and increased ovarian and reproductive tract responses to $\mathrm{PMSG} / \mathrm{hCG}$ treatment in pubertal crossbred gilts (Zięcik et al., 2002).

\section{CONCLUSIONS}

Our results are in agreement with earlier observations, dietary energy source affects the postprandial plasma insulin levels in mature gilts, when their diet is given in a twice-daily feeding regimens. Additionally a similar effect was observed in prepubertal gilts, when their diet was given in three but not four equal portions. However, three times-daily feeding increased insulin concentrations in blood samples during a 25 day feeding period had no significant effect on ovarian and follicular development in prepubertal gilts of the Polish Landrace breed. 


\section{REFERENCES}

Booth P.J., Cosgrove J.R., Foxcroft G.R., 1996. Endocrine and metabolic responses to realimentation in feed-restricted prepubertal gilts: associations among gonadotropins, metabolic hormones, glucose, and uteroovarian development. J. Anim. Sci. 74, 840-848

Britt J.H., Day B.N., Webel S.K., Brauer M.A., 1989. Induction of fertile estrus in prepubertal gilts by treatment with a combination of pregnant mare's serum gonadotropin and human chorionic gonadotropin. J. Anim. Sci. 67, 1148-1153

Catt K.J., Dufau M.L., 1975. Gonadal receptors for luteinizing hormone and chorionic gonadotropin. Methods Enzymol. 37, 167-193

Cox N.M., Stuart M.J., Althen T.G., Bennet W.A., Miller H.W., 1987. Enhancement of ovulation rate in gilts by increasing dietary energy and administering insulin during follicular growth. J. Anim. Sci. 64, 507-516

Dailey R.A., Clark J.R., First N.L., Chapman A.B., Casida L.E., 1972. Effects of high and low feeding at two stages of the estrous cycle on follicular development in gilts from four genetic groups. J. Anim. Sci. 35, 1210-1215

Greenwood F.C., Hunter W.H., Glover J.S., 1963. The preparation of ${ }^{131}$ l-labelled human growth hormone of high specific radioactivity. Biochem. J. 89, 114-123

Hoffmann L., Schiemann R., Jentsch W., 1972. Energetische Verwertung der Nährstoffe in Futterrationen. Deut. Landwverlag, Berlin, pp.118-161

Hughes P.E., 1982. Factors affecting the natural attainment of puberty in the gitt. In: D.J.A. Colc, G.R. Foxcroft (Editors). Control of Pig Reproduction. Butterworth, London, pp. 117-138

Jana B., Dusza L., Sobczak J., 1996. Effect of exogenous porcine prolactin (pPRL) on LH plasma concentration and on the release of $\mathrm{GnRH}$ in vitro from stalk median eminence in prepubertal gilts. Anim. Reprod. Sci. 41, 295-304

Kirchick H.J., Keyes P.L., Frye B.E., 1982. Restoration of the LH surge and ovulation by insulin in alloxan-diabetic immature rats treated with pregnant mare's serum gonadotrophin. Acta. Endocrinol. 100, 266-273

Kotwica J., Krzymowski T., Dębek J., 1978. Cannulation vein vessels for endocrinological studies (in Polish) Med. wet. 34, 118-120

Lowry O.H., Rosebrough N.J., Faar A.L., Randall R.J., 1951. Protein measurement with the Folin phenol reagent. J. Biol. Chem. 193, 265-275

Matamoros I.D., Cox N.M., Moore A.B., 1990. Exogenous insulin and additional energy affect follicular distribution, follicular steroid concentrations, and granulosa cell human chorionic gonadotropin binding in swine. Biol. Reprod. 43, 1-7

Ponter A.A., Salter D.N., Morgan L.M., Flatt P.R., 1991. The effect of energy source and feeding level on the hormones of the entero-insular axis and plasma glucose in the growing pig. Brit. J. Nutr. 66, 187-197

Robertson G.L., Casida L.E., Grummer R.H., Chapman A.B., 1951. Some feeding and managements factors affecting age at puberty and related phenomena in Chester White and Polish China gilts. J. Anim. Sci. 10, 847-856

Siegel L.I., Wade G.N., 1979. Insulin withdrawal impairs sexual receptivity and retention of brain cell nuclear estrogen receptors in diabctic rats. N'curoendocrinology 29, 200-206

Tokach M.D., Pettigrew J.E., Dial G.D., Wheaton J.E., Crooker B.A., Johnston L.J., 1992. Infiuence of glucose infusions on luteinizing hormone secretion in the energy-restricted, primiparous, lactating sow. J. Anim. Sci. 70, 2202-2206

Van den Brand H., Soede N.M., Schrama J.W., Kemp B., 1997. Effects of dietary energy source on plasma glucose and insulin concentration in gilts. J. Anim. Plıysiol. Anim. Nutr. 79, 27-32 
Ziecik A.J., Esbenshade K.L., Britt J.H., 1989. Etfects of a gonadotropin-releasing hormone antagonist on gonadotropin secretion and gonadal development in neonatal pigs. J. Reprod. Fertil. 87, 281-289

Zięcik A.J., Kapelański W., Zaleska M, J. Riopérez., 2002. Effect of glucose supplemented diet on natural and gonadotropins induced puberty attainment in gilts. J. Anim. Feed Sci. 11, 461-469

Zimmerman D.R., Spies H.G., Rigor E.M., SelfH.L. Casida L.E., 1960. Effects of restricted feeding, crossbreeding, and seasons of birth at age of puberty in swine. J. Anim. Sci. 19, 687-694

\section{STRESZCZENIE}

\section{Wplyw diety i częstotliwości karmienia na poziom insuliny oraz rozwój jajnika u niedojrza- lych plciowo loszek}

Insulina może korzystnie wpływać na procesy rozrodcze. Celem badań było określenic wpływu diet zawicrających różne główne źródła energii (skrobię, glukozę, tłuszcz) oraz podziclonych na 2, 3 i 4 porcje dziennie, na poposiłkowy poziom insuliny, jak równicż oszacowanie wpływu 3-krotnego karmienia na rozwój pęcherzyków jajnikowych u niedojrzałych płciowo loszek.

W Doświadczeniu 1, 18 loszek mieszańców w wieku ok. 142 dni otrzymywało trzy diety $(\mathrm{n}=6)$ w trzech częstotliwościach karmienia (2, 3 i 4 razy dziennie). Doświadczenia poprzedzono trzydniowym okresem adaptacji do diety i częstotliwości karmienia. Czwartego dnia krew pobierano przed, w trakcie i po karmieniu. Następnego dnia zmieniano częstotliwość karmienia tą samą dietą i procedurę powtarzano. Poziom glukozy i insuliny we krwi oznaczano odpowiednio metodą enzymatyczną i radioimmumologiczną.

W Doświadczeniu 2, loszki PBZ ( $n=44)$ podziclono na trzy grupy i podawano dictę skrobiową (S), glukozową $(\mathrm{G})$ i tłuszczową $(\mathrm{T})$ w trzech jednakowych porcjach o godzinic 8:00, 13:00 i 18:00. Po 25 dniach karmienia loszki ubito w celu określenia masy jajników, rozwoju pęcherzyków jajnikowych i ogólnej liczby receptorów LH w jajniku.

Podstawowy poziom glukozy byl podobny przy skarmianiu wszystkich diet podawanych 3 - i 4-krotnje $w$ ciagu dnia ( 3 razy dziennie: $50,8 \pm 4,9,56,2 \pm 4,0,56,3 \pm 7,4 \mathrm{mg} / \mathrm{dl} ; 4$ razy dziennie: 53 , $\pm \mathrm{J}, 7,65,8 \pm 5,9,58,3 \pm 7,5 \mathrm{mg} / \mathrm{dl})$, lecz różnił się gdy świnie żywiono 2-krotnie $(71,4 \pm 10,4,40,8 \pm 3,9$, $53,6 \pm 8,6 \mathrm{mg} / \mathrm{dt}$; odpowiednio skrobia, glukoza, tłuszcz; glukoza vs skrobia $\mathrm{P}<0,05)$. Podstawowy poziom insuliny we krwi był podobny przy skarmianiu trzech diet i przy różnych częstotliwościach podawania paszy ( 2 razy dziennic: $7.8 \pm 1.4,9.3 \pm 0.99,9.50 \pm 0.9 \mu \mathrm{IU} / \mathrm{ml} ; 3$ razy dziennie: $6.2 \pm 1.4$, $10.3 \pm 1.0,8.6 \pm 1.0 \mu \mathrm{IU} / \mathrm{ml}$ i $4 \mathrm{razy}$ dziennie: $8.5 \pm 1.6,7.9 \pm 0.8,8.2 \pm 2.7 \mu \mathrm{IU} / \mathrm{ml}$; odpowiednio skrobia, glukoza, tłuszcz.). Po karmieniu poziom insuliny u loszek otrzymujących dietę skrobiową lub z glukozą wzrastał szybciej w porównaniu z dictą thuszczową, niezależnie od częstotliwości podawania paszy. Pole pod krzywą dla poziomu insuliny we krwi było większe w przypadku diety z glukozą niż z tłuszczem ( 2 razy dziennie: $6870 \pm 656$ vs $4028 \pm 75$ 1; 3 razy dziennie: $6314 \pm 718$ vs $3274 \pm 472$ jednostek umownych, odpowiednio), i miało wartość pośrednia przy podawaniu diety skrobiowej (6104 \pm 762 i $3855 \pm 729$, odpowiednio) i nie różniło się istotnie od wartości uzyskanych przy dwóch pozostałych dictach. Podawanie wszystkich diet przez 25 dni nie miało wplywu na masę (g) jajników, liczbę i rozmiar zdrowych oraz atretycznych pęcherzyków, ani na koncentrację receptorów LH.

Uzyskane wyniki potwierdzają wcześnicjsze obserwacje uzyskane dla dojrzałych loszek, że rodzaj źródła energii w diecie wpływa na poposiłkowy poziom insuliny, gdy paszę podawano $w$ dwóch porcjach. Podobny efekt zaobserwowano u niedojrzałych płciowo loszek, gdy dietę podawano w dwóch i trzech, lecz, nie czterech jednakowych porcjach. Trzykrotne zwiększenic zawartości insuliny w krwi w ciagu doby w ciagu 25 dni nie miało wpływu na rozwój pęcherzyków jajnikowych i jajników u niedojrzałych płciowo loszek rasy PBZ. 